\title{
Interleukin-12p70 Expression by Dendritic Cells of HIV-1-Infected Patients Fails to Stimulate gag-Specific Immune Responses
}

\author{
Ellen Van Gulck, ${ }^{1}$ Nathalie Cools, ${ }^{2}$ Derek Atkinson, ${ }^{1}$ Lotte Bracke, ${ }^{1}$ Katleen Vereecken, ${ }^{1}$ Marc \\ Vekemans, ${ }^{3}$ Viggo F. I. Van Tendeloo, ${ }^{2,4}$ Zwi N. Berneman, ${ }^{2,4}$ and Guido Vanham ${ }^{1,5}$ \\ ${ }^{1}$ Virology Unit, Department of Microbiology, Institute of Tropical Medicine (ITMA), 2000 Antwerp, Belgium \\ ${ }^{2}$ Laboratory of Experimental Hematology, Vaccine and Infectious Disease Institute (Vaxinfectio), \\ Faculty of Medicine and Health Sciences, University of Antwerp, 2610 Wilrijk, Belgium \\ ${ }^{3}$ Unit of HIV/STD, Department of Clinical Sciences, ITMA, 2000 Antwerp, Belgium \\ ${ }^{4}$ Center for Cell Therapy and Regenerative Medicine, Antwerp University Hospital (UZA), Wilrijkstraat 10, 2650 Edegem, Belgium \\ ${ }^{5}$ Department of Biomedical Sciences, Faculty of Pharmaceutical, Veterinary and Biomedical Sciences, University of Antwerp and \\ Faculty of Medicine and Pharmacy, Free University of Brussels, Belgium
}

Correspondence should be addressed to Nathalie Cools, nathalie.cools@uza.be

Received 16 December 2011; Revised 28 March 2012; Accepted 19 May 2012

Academic Editor: Elias A. Said

Copyright ( 92012 Ellen Van Gulck et al. This is an open access article distributed under the Creative Commons Attribution License, which permits unrestricted use, distribution, and reproduction in any medium, provided the original work is properly cited.

\begin{abstract}
A variety of immune-based therapies has been developed in order to boost or induce protective CD8 ${ }^{+} \mathrm{T}$ cell responses in order to control HIV replication. Since dendritic cells (DCs) are professional antigen-presenting cells (APCs) with the unique capability to stimulate naïve $\mathrm{T}$ cells into effector $\mathrm{T}$ cells, their use for the induction of HIV-specific immune responses has been studied intensively. In the present study we investigated whether modulation of the activation state of DCs electroporated with consensus codon-optimized HxB2 gag mRNA enhances their capacity to induce HIV gag-specific T cell responses. To this end, mature DCs were (i) co-electroporated with mRNA encoding interleukin (IL)-12p70 mRNA, or (ii) activated with a cytokine cocktail consisting of R848 and interferon (IFN)- $\gamma$. Our results confirm the ability of HxB2 gag-expressing DCs to expand functional HIV-specific $\mathrm{CD}^{+} \mathrm{T}$ cells. However, although most of the patients had detectable gag-specific CD8 ${ }^{+} \mathrm{T}$ cell responses, no significant differences in the level of expansion of functional $\mathrm{CD}^{+} \mathrm{T}$ cells could be demonstrated when comparing conventional or immune-modulated DCs expressing IL-12p70. This result which goes against expectation may lead to a re-evaluation of the need for IL-12 expression by DCs in order to improve T-cell responses in HIV-1-infected individuals.
\end{abstract}

\section{Introduction}

Accumulating evidence suggests that human immunodeficiency virus (HIV)-specific T cells play a critical role in controlling viral replication in chronic HIV infection [1-5]. Although most individuals show detectable levels of HIVspecific $\mathrm{CD} 8^{+} \mathrm{T}$ cell responses [6], a defect of HIV-specific $\mathrm{CD}^{+} \mathrm{T}$ cells to expand in vitro has been previously reported [7]. Evaluation of ex vivo $\mathrm{CD}^{+} \mathrm{T}$ cells further indicates qualitative defects, such as low avidity, limited polyfunctionality, and $\mathrm{T}$ cell exhaustion which could explain why, despite a clear-cut cellular immune response, most HIV-infected patients show clinical progression in the absence of antiretroviral therapy. Even under highly active antiretroviral therapy (HAART), the functional capacity of HIV-specific $\mathrm{CD}^{+} \mathrm{T}$ cells, that is, secretion of soluble mediators and ability to expand, is not restored $[8,9]$. Therefore, a major goal of many candidate HIV therapeutic vaccines in development is to stimulate the cellular arm of the immune system, in particular HIV-specific $\mathrm{CD}_{4}^{+}$and $\mathrm{CD} 8^{+}$ $\mathrm{T}$ cells [10]. Unfortunately, these new therapies and vaccines do not deliver the expected success yet. For instance, Autran 
et al. reported significantly elevated viral loads in chronically infected patients compared to the placebo group after discontinuation of therapy following immunization with vCP1452, the HIV-recombinant canarypox vaccine (ALVACHIV) [11]. Remarkably, patients receiving more doses of the vaccine required treatment resumption more rapidly. Analysis of these results strongly suggested that the vaccine failed to elicit protective HIV-specific $\mathrm{CD} 8^{+} \mathrm{T}$ cell responses [12]. Moreover, mainly induction of activated $\mathrm{CD} 4^{+} \mathrm{T}$ cell responses was demonstrated in vaccines, which increased target cell availability and rendered patients potentially more susceptible to disease progression. This observation underlined the importance of potent $\mathrm{CD} 8^{+} \mathrm{T}$ cell responses for viral control and strongly suggested that, in order to provide a more effective strategy to induce viral control, it is important that therapeutic vaccine strategies induce robust and broad $\mathrm{CD} 8^{+} \mathrm{T}$ cell responses, while only modestly activating $\mathrm{CD} 4^{+} \mathrm{T}$ cell responses.

Since dendritic cells (DCs) are professional antigenpresenting cells (APCs) with the unique capability to stimulate naïve $\mathrm{T}$ cells into effector $\mathrm{T}$ cells $[13,14]$, their use for the induction of HIV-specific immune responses has been studied intensively. Some of the key factors that determine the ability of DCs to improve the quality and quantity of $\mathrm{T}$ cell responses include the antigen-loading strategy, the expression levels of costimulatory molecules and cytokines, as well as signals for activation of DCs [15]. We [16-18] and others [19-25] have previously shown that DCs transfected with mRNA-encoding antigens are superior to other loading strategies for induction of immune responses. Additionally, a multitude of products has been used for activation of DCs, including members of the tumor necrosis factor (TNF) family, Toll-like receptor (TLR) ligands, and type I and II interferons; other activators include various cytokines, chemokines, and prostaglandins. The current golden standard method to induce activation of DCs for clinical application is based on a cocktail of proinflammatory cytokines (IL-1 $\beta$, TNF- $\alpha$ and IL-6) and prostaglandin (PG) $\mathrm{E}_{2}$ [26]. It has, however, been demonstrated earlier that a simplified cocktail consisting of only TNF- $\alpha$ and $\mathrm{PGE}_{2}$ generates a similar mature HLA$\mathrm{DR}^{+} \mathrm{CD} 86^{+} \mathrm{CD} 80^{+} \mathrm{CD} 83^{+} \mathrm{CCR} 7^{+}$DC phenotype $[27,28]$. While $\mathrm{PGE}_{2}$ increases the expression of CCR7 and hence the capacity of DCs to migrate to the regional lymph nodes through chemotaxis by CCL-19 and/or -21 [29], $\mathrm{PGE}_{2}$ also inhibits interleukin (IL)-12p70 secretion by DCs, which is otherwise necessary for the development of an effective Th1 immune response $[30,31]$. In order to increase IL-12p70 secretion, DCs can be electroporated with mRNA encoding IL-12p70 [32]. However, too much IL-12 production can paradoxically contribute to T cell exhaustion $[33,34]$. Since this should be avoided, conditions that induce endogenous production of IL-12p70 by DCs could be used [35]. Indeed, it was reported that DCs matured with type II interferon (IFN), that is, IFN- $\gamma$, together with IL- $1 \beta$ and TNF- $\alpha$ overcome such maturation-associated exhaustion $[36,37]$.

We previously demonstrated that DCs (from HAARTtreated individuals), electroporated with consensus codonoptimized HxB-2 gag mRNA or autologous proviral-derived gag mRNA, efficiently expand HIV-specific T cells that secrete IFN- $\gamma$, IL-2, perforin, and other cytokines $[16,17]$. In the present study we aimed at enhancing the immunogenic potential of DCs by varying the signals for activation of DCs and analyzing the effect of those activated gag-expressing DCs on various aspects of $g a g$-specific $\mathrm{CD} 8^{+} \mathrm{T}$ cell responses, such as the ability to produce soluble mediators and to expand after restimulation with gag-derived peptides.

A variety of immune-based therapies have been developed in order to boost or induce protective $\mathrm{CD}^{+} \mathrm{T}$ cell responses in order to control HIV replication. Since dendritic cells (DCs) are professional antigen-presenting cells (APCs) with the unique capability to stimulate naïve $\mathrm{T}$ cells into effector $\mathrm{T}$ cells, their use for the induction of HIV-specific immune responses has been studied intensively. In the present study we investigated whether modulation of the activation state of DCs electroporated with consensus codon-optimized HxB2 gag mRNA enhances their capacity to induce HIV gag-specific T cell responses. To this end, mature DCs were (i) co-electroporated with mRNA encoding interleukin (IL)-12p70 mRNA, or (ii) activated with a cytokine cocktail consisting of R848 and interferon (IFN)- $\gamma$. Our results confirm the ability of HxB2 gag-expressing DCs to expand functional HIV-specific $\mathrm{CD} 8^{+} \mathrm{T}$ cells. However, although most of the patients had detectable gag-specific $\mathrm{CD}^{+} \mathrm{T}$ cell responses, no significant differences in the level of expansion of functional $\mathrm{CD}^{+} \mathrm{T}$ cells could be demonstrated when comparing conventional or immunemodulated DCs expressing IL-12p70. This result which goes against expectation may lead to a re-evaluation of the need for IL-12 expression by DCs in order to improve T-cell responses in HIV-1-infected individuals.

\section{Materials and Methods}

2.1. Study Population. Peripheral blood samples $(100 \mathrm{~mL})$ from HAART-treated HIV-1-seropositive individuals were recruited at the clinical department of the Institute of Tropical Medicine of Antwerp according to institutional guidelines and after obtaining informed consent. Patients included had undetectable viral load levels and a $\mathrm{CD} 4^{+} \mathrm{T}$ cell count above 300 cells $/ \mu \mathrm{L}$. The study was approved by the Institute's Ethics Committee and followed the tenets of the Declaration of Helsinki.

2.2. Plasmid DNA Constructs. The pGEM4Z/hgag/A64 (pGEMhgag) plasmid was kindly provided by Professor Kris Thielemans (Laboratory of Physiology and Immunology, Free University of Brussels) and was used to prepare a humanized (codon-optimized) mRNA encoding the HxB-2 HIV-1 gag protein (hHxB-2 gag) [38]. The pGEM4Z/hIL12/A64 plasmid was kindly provided by Professor Erik Hooijberg (Medical Center of the Vrije Universiteit, Amsterdam, The Netherlands) and was used to prepare mRNA encoding IL-12p70 [32]. These plasmids were propagated in E. coli supercompetent cells (Stratagene, La Jolla, CA, USA) and purified on endotoxin-free Qiagen-tip 100 columns (Westburg, Leusden, The Netherlands). Next, the plasmids 
were linearized with SpeI (MBI Fermentas, St. Leon-Rot, Germany), purified using a PCR purification kit (Qiagen), and used as a DNA template for in vitro transcription. In vitro transcribed 5' capped mRNA was generated using T7 mMessage mMachine kit (Ambion, Austin, TX, USA). Purification of mRNA was performed by DNase I digestion followed by $\mathrm{LiCl}$ precipitation, according to manufacturer's instructions. RNA concentration was assayed by spectrophotometrical analysis and stored at $-20^{\circ} \mathrm{C}$ in small aliquots.

2.3. Generation of DCs. Peripheral blood mononuclear cells (PBMCs) were isolated by Lymphoprep (Lucron, De Pinte, Belgium) gradient separation. Next, CD $14^{+}$monocytes were directly isolated by $\mathrm{CD} 14^{+}$immunomagnetic selection (CD14 Reagent, Miltenyi Biotec, Bergisch Gladbach, Germany) according to manufacturer's instructions and directly used for in vitro DC differentiation as described before [39] in medium containing $2.5 \%$ pooled human serum (PHS, PAA company, Austria). The CD14-depleted cell fraction, designated as peripheral blood lymphocytes (PBLs), was cryopreserved and stored at $-80^{\circ} \mathrm{C}$ for later use in $\mathrm{DC} / \mathrm{T}$ cell cocultures. On day 6, DCs were activated (i.e., converted to mature DCs (mDCs)) for 24 hours by adding a cocktail of proinflammatory cytokines consisting of $2.5 \mathrm{ng} / \mathrm{mL}$ TNF- $\alpha$ (Roche Molecular Biochemicals, Mannheim, Germany) and $10^{-7} \mathrm{M}$ prostaglandin $\mathrm{E}_{2}$ ( $\mathrm{PGE}_{2}$, Sigma, St Louis, MO USA). In parallel, DCs were simultaneously generated under the same conditions, but the "basic" cocktail was supplemented with the following factors: $25 \mathrm{ng} / \mathrm{mL}$ IFN- $\gamma$ (Invitrogen, Merelbeke, Belgium) and $2 \mu \mathrm{g} / \mathrm{mL}$ R848 (Alexis, Zandhoven, Belgium) or $1 \mu \mathrm{g} / 10^{6}$ cells mRNA encoding IL-12p70 was coelectroporated with gag mRNA.

2.4. DC Electroporation. After incubation with the maturation cocktail for 24 hours, DCs were harvested and electroporated with mRNA encoding gag antigen and when indicated with mRNA encoding IL-12p70. Electroporation of in vitro transcribed mRNA was performed as described previously $[18,40]$. After electroporation, cells were directly used in DC/T cell coculture experiments.

2.5. Cytokine Release Assay. Quantitative detection of the cytokine expression profile of DCs was determined using a Th1/Th2 multiplex fluorescent bead immunoassay (Bender MedSystems, Vienna, Austria), according to manufacturer's instructions.

2.6. DC-Mediated Stimulation of HIV gag-Specific T Cell Responses. To evaluate the capacity of DCs to expand gagspecific T cells, gag mRNA-electroporated mature DCs were cocultured with autologous PBLs (ratio $1: 10$ ) in RPMI 1640 medium supplemented with 2.5\% PHS. After 7 days, PBLs were harvested and analyzed using a "restimulation" IFN$\gamma$ ELISpot assay. Furthermore, a fraction of the cells was stimulated for an additional 7 days with cryopreserved HIV1 gag mRNA-electroporated autologous DCs [40]. At day 14 , these cells were analyzed using an IFN- $\gamma$ ELISpot assay. In parallel, unstimulated PBLs (day 0) and PBLs stimulated with mock-electroporated DCs (day 7 and day 14) were used as a control.

2.7. IFN- $\gamma$ ELISpot Assay. For detection of IFN- $\gamma$-producing HIV gag-specific activated T cells, PBLs were incubated at a concentration of $2.5 \times 10^{5}$ cells/well with $g a g$ peptide pool $(2 \mu \mathrm{g} / \mathrm{mL}$, NIH, Maryland, USA) in anti-human IFN$\gamma$ antibody (Diaclone, Besancon, France) coated 96 wellplates (Millipore), for at least 16 hours and not more than 24 hours. For the detection of spots, a biotin-labelled antihuman IFN- $\gamma$ antibody (Diaclone) was used. Frequencies of antigen-specific IFN- $\gamma$-secreting cells were calculated based on the number of spots counted using an automated iSpot Reader system (AID GmbH, Strassberg, Germany). For the definition of a positive response, guidelines from the Cancer Vaccine Consortium were followed: per $10^{6}$ PBLs, the mean antigen-specific spot count for a donor and condition must be greater than or equal to 50 spots and at least three times as high as the background reactivity $[41,42]$.

2.8. Statistics. The results are expressed as mean \pm standard deviation. Comparisons were validated using Wilcoxon signed rank test and 2-way Anova using GraphPad version 5 software (Prism, La Jolla, CA, USA). A $P$ value of $\leq 0.05$ was considered as statistically significant.

\section{Results}

3.1. Do Immune-Modulated DCs Produce IL-12p70 and/or Other Cytokines? We have previously described that mRNA electroporation is a highly efficient tool to induce transgene expression in monocyte-derived dendritic cells [16-18]. Indeed, electroporation of Mo-DCs with HxB-2 gag mRNA resulted in efficient expression of gag protein compared to mock-electroporated DCs (see Supplementary Figure 1(A) available online at doi: 10.1155/2012/184979). Here, DCs were activated using a cocktail of proinflammatory cytokines consisting of (i) TNF- $\alpha$ and $\mathrm{PGE}_{2}$ or (ii) TNF- $\alpha, \mathrm{PGE}_{2}$, IFN- $\gamma$, and R848. Simultaneously, TNF- $\alpha / \mathrm{PGE}_{2}$ matured DCs were coelectroporated with IL-12p70-encoding mRNA. Next, IL-12p70 expression was assessed by means of IL12 p70 fluorescent bead immunoassay, 24 hours after electroporation. We demonstrate efficient translation of mRNA into secreted IL-12p70 protein, at concentrations ranging between 1 and $8 \mathrm{ng} / \mathrm{mL}$ by both DCs electroporated with IL-12p70-encoding mRNA (Figure 1(a)) and DCs activated using a cocktail of proinflammatory cytokines supplemented with IFN- $\gamma$ and R848 (Figure 1(b)). In contrast, untreated DCs (i.e., immature DCs (iDCs)), mock-electroporated DCs or DCs activated with TNF- $\alpha$ and $\mathrm{PGE}_{2}$ alone did not secrete IL-12p70 (Figures 1(a) and 1(b)). In addition, the culture supernatant was collected at different time points after activation of DCs. As evidenced in this washout experiment, we are able to detect IL-12p70 secretion up to 72 hours after activation of DCs, albeit at significantly reduced levels (Figures 1(a) and 1(b)). Noteworthy, coelectroporation of mRNA encoding IL-12p70 and hHxB-2 gag did not affect the 


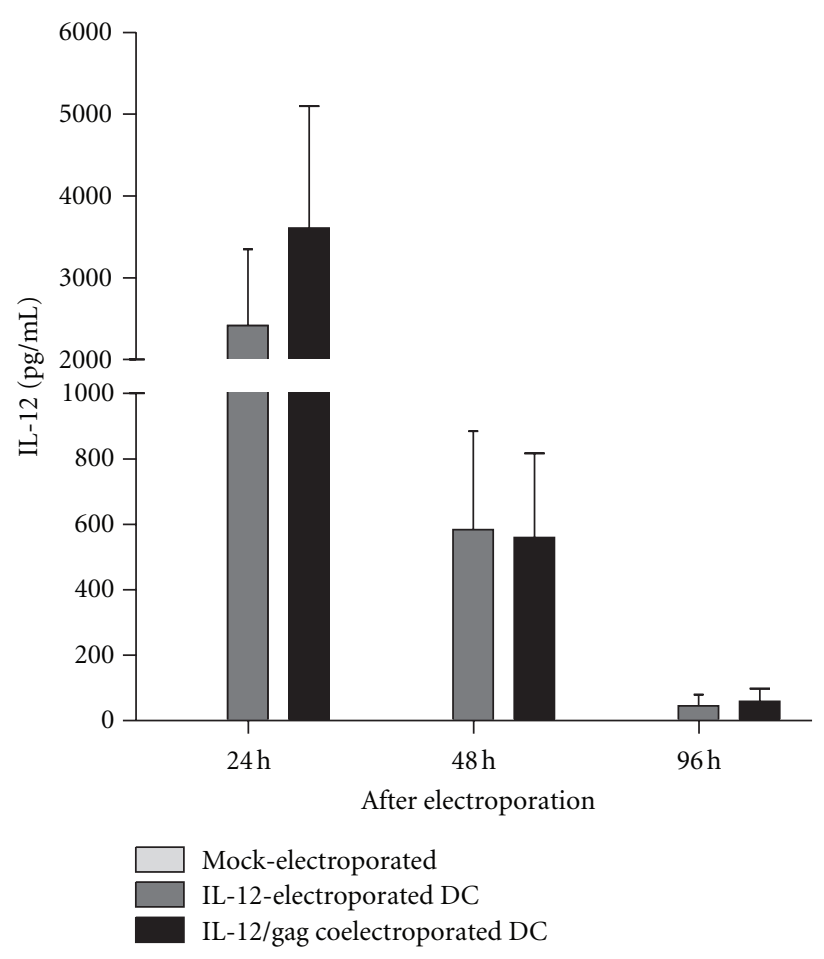

(a)

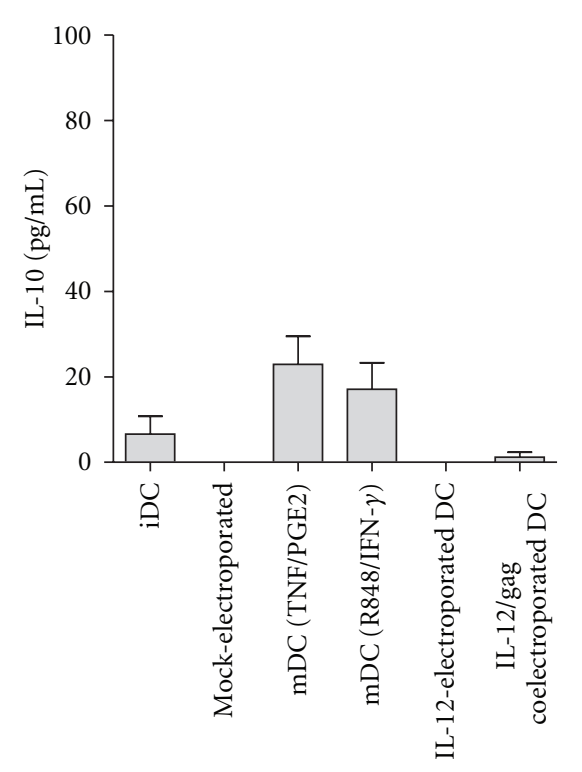

(c)

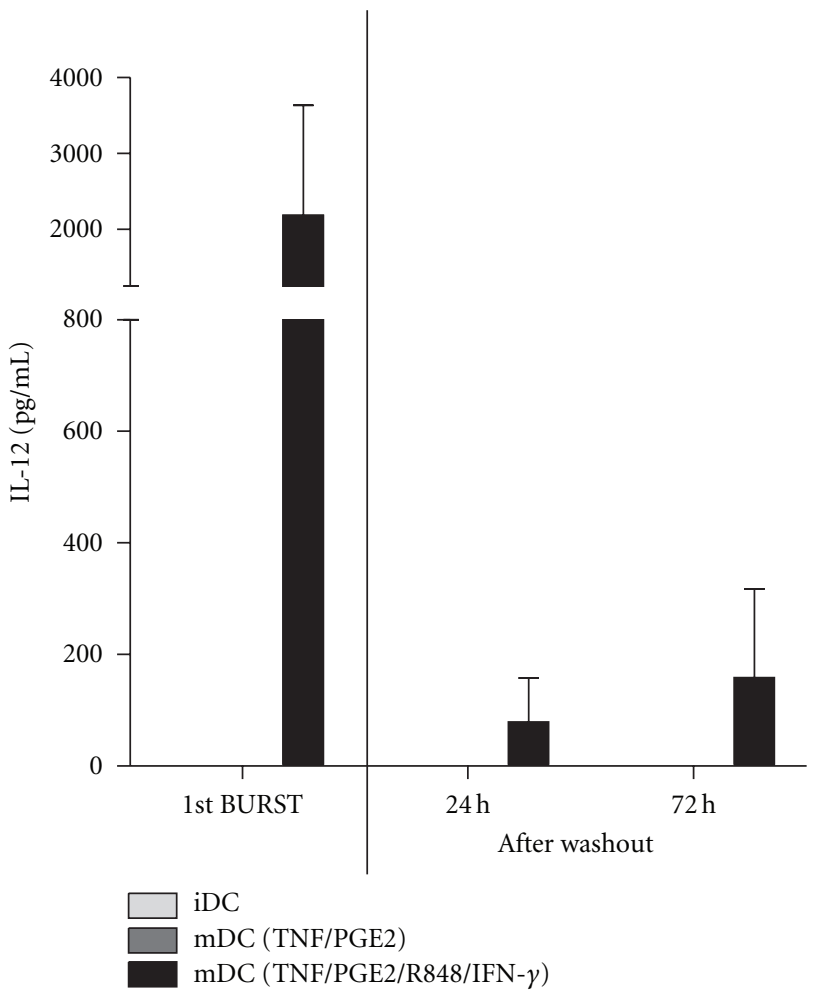

(b)

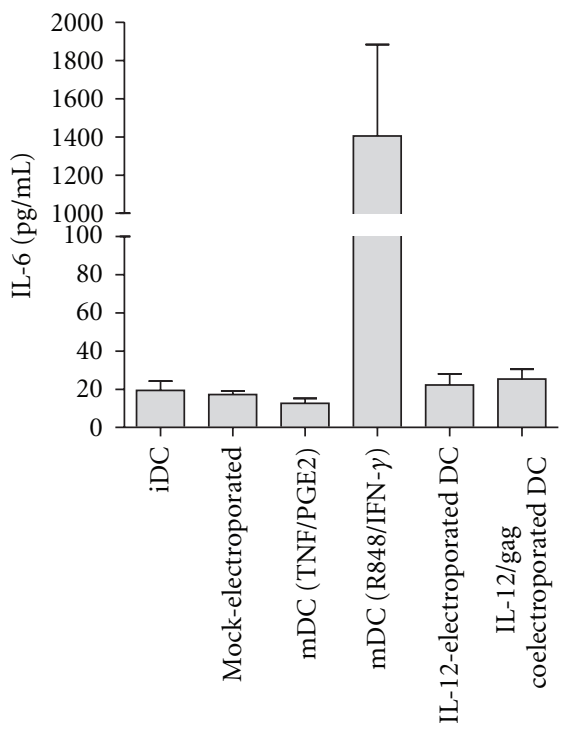

(d)

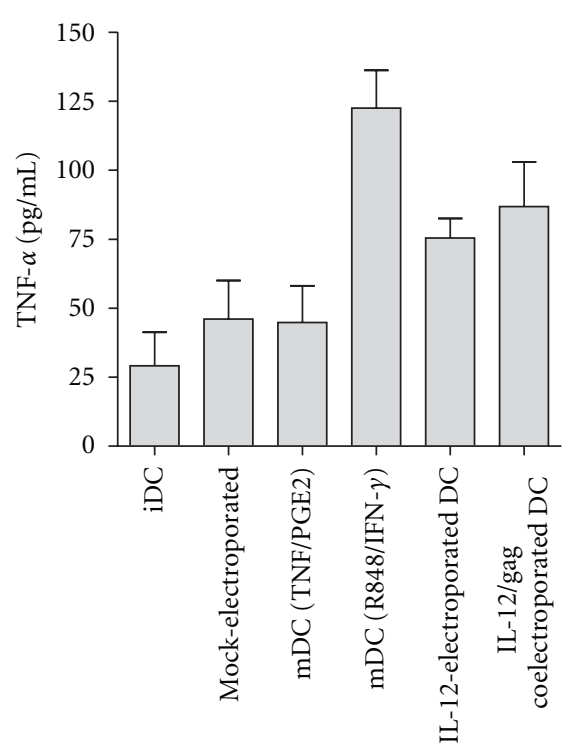

(e)

FIGURE 1: Production of pro- and anti-inflammatory cytokines by DCs modulated to express IL-12p70. (a) IL-12 secretion by DCs electroporated with IL-12p70-encoding mRNA. DCs were examined after incubation with a proinflammatory cytokine cocktail consisting of TNF- $\alpha$ and $\mathrm{PGE}_{2}$ and electroporated with mRNA encoding IL-12p70 or with IL-12p70-encoding mRNA in combination with hHxB-2 gagencoding mRNA. As a control mock-electroporated mature DCs were examined. DC culture supernatant was collected $24 \mathrm{~h}, 48 \mathrm{~h}$, and $96 \mathrm{~h}$ after electroporation. Results are shown as mean \pm standard deviation $(n=5)$. (b) IL-12 secretion by immune-modulated DCs. DCs were examined after incubation with a proinflammatory cytokine cocktail consisting of TNF- $\alpha$ and PGE $_{2}$ or activated under the same conditions supplemented with R848 and IFN- $\gamma$. As a control untreated, that is, immature DCs (iDCs) were examined. DC culture supernatant was collected $24 \mathrm{~h}$ after activation with proinflammatory stimuli, as well as $24 \mathrm{~h}$ and $72 \mathrm{~h}$ after a washout experiment. Results are shown as mean \pm standard deviation $(n=5)$. (c), (d), and (e) Cytokine secretion by DCs activated under different experimental conditions and after a $24 \mathrm{~h}$ washout period. Values are shown for (c) IL-10, (d) IL-6, and (e) TNF- $\alpha$. Results are shown as mean \pm SD $(n=5)$. 
level of transgene expression (Figure 1(a) and Supplementary Figure 1(B)). Furthermore, secretion of other pro- and anti-inflammatory cytokines, that is, IL-10, IL- 6 and TNF- $\alpha$, was evaluated after washout as well. Whereas DCs stimulated with a cocktail consisting of TNF- $\alpha, \mathrm{PGE}_{2}$, IFN- $\gamma$, and R848 secreted significantly higher levels of IL-6 (Figure 1(d)), no differences could be detected in other investigated experimental conditions (Figures 1(c), 1(d) and 1(e)).

3.2. Can IL-12 mRNA Electroporation of DCs Improve the Expansion of HIV gag-Specific T Cells? Since IL-12 is a key cytokine supporting cytotoxic $\mathrm{CD}^{+} \mathrm{T}$ cell responses through the polarization of a Th1 immune response [30,31], we investigated if hHxB-2 gag mRNA-electroporated DCs cotransfected with IL-12p70 mRNA can expand the number of cytokine-secreting HIV gag-specific T cells. To this end, DCs matured with TNF- $\alpha$ and $\mathrm{PGE}_{2}$ were electroporated with mRNA encoding HIV gag or with $I L-12 p 70$ mRNA or with both mRNAs and subsequently cocultured with autologous PBLs for 1 week. Next, stimulated PBLs were restimulated with HIV gag peptide pool in an IFN- $\gamma$ and/or IL-2 ELISpot assay. The induced immune responses were compared with the responses generated by PBLs stimulated with HIV gag peptide pool at day 0. As demonstrated in Figure 2, DCs electroporated with HIV gag mRNA induced expansion of HIV gag-specific T cells (Figures 2(a) and 2(b)). However, DCs cotransfected with IL-12p70 and HIV gag mRNA did not enhance expansion of HIV gag-specific T cells (Figures 2(c) and 2(d)). An equally efficient expansion of HIV gag-specific T cells was observed after seven days, regardless of which DC maturation cocktail was used (Figures 2(e) and 2(f)).

\subsection{Can an IL-12-Inducing DCs Maturation Cocktail Enhance} the Expansion of HIV gag-Specific T Cells? Previously, it has been shown by others that stimulation of DCs with R848 together with IFN- $\gamma$ can abrogate the $\mathrm{PGE}_{2}$-induced impairment of DCs to produce IL-12p70. In other words, DCs stimulated with a cocktail consisting of TNF- $\alpha, \mathrm{PGE}_{2}$, IFN- $\gamma$, and R848 can secrete high amounts of IL-12p70 [36, 37]. In contrast to IL-12p70-cotransfected DCs, PBLs stimulated for one week with DCs matured with this "improved" cytokine cocktail produced more IFN- $\gamma$ than PBLs stimulated with standard matured DCs, albeit not statistically significant (Figures 3(a), 3(c), and 3(e)). However, this improved maturation cocktail, consisting of TNF- $\alpha, \mathrm{PGE}_{2}, \mathrm{R} 848$, and IFN- $\gamma$, did not enhance the expansion of HIV gag-specific IL-2-secreting T cells.

3.4. Can Immune-Modulated hHxB-2 gag mRNA-Electroporated DCs Induce Long-Lasting HIV gag-Specific Immune Responses? Besides the need for potent $\mathrm{CD}^{+}$and $\mathrm{CD} 8^{+} \mathrm{T}$ cells, duration of the cellular response is another critical issue in the development of successful HIV vaccines. To evaluate this aspect, PBLs were stimulated for a second time with hHxB-2 gag mRNA-electroporated mature DCs at day 7. At day 14, stimulated PBLs were restimulated with HIV gag peptide pool in an ELISpot assay in order to detect antigenspecific IFN- $\gamma$ and/or IL-2 secretion. While stimulation with DCs did not result in a decline of HIV gag-specific IFN- $\gamma$ producing $\mathrm{T}$ cells, no differences in the expansion of HIV gag-specific T cells could be observed after 14 days, regardless of which maturation cocktail was used (Figure 4).

\section{Discussion}

DC-based immunotherapy has been demonstrated to be safe with only minor local side effects reported in some clinical trials and has been shown to have clinical efficacy in HIVinfected patients [43-52]. Although an impressive amount of data has been obtained from the clinical trials completed thus far, no final conclusions can be drawn, because the design of the various clinical trials was different, few were really placebo-controlled and blinded, and all include only limited number of patients.

To mount an efficient immune response, at least three signals are necessary $[13,14,53]$. The first signal is the recognition of antigen peptide/major histocompatibility complex (MHC) conjugates presented by APCs. The second signal is provided through costimulatory molecules. The best-characterized costimulatory receptor-ligand interaction is that of CD28, expressed on naïve and memory T cells, with its ligands CD80 and CD86, expressed on APCs, such as DCs (reviewed in [54-56]). The third signal polarizes the effector T cell response toward a Th1, Th2, Th17, or Treg phenotype and is delivered by DCs through a number of soluble and membrane-bound ligands. One well-studied third signal agent is IL-12p70 for the induction of Th1 and cytotoxic T lymphocytes (CTLs) [57]. Until now, DCs matured with a proinflammatory cytokine-cocktail consisting of IL- $1 \beta$, IL6 , TNF- $\alpha$, and $\mathrm{PGE}_{2}$ have been the most commonly used in clinical settings $[47,52]$, although it is known that these DCs fail to produce IL-12p70 [58]. As an alternative, it was reported that $\mathrm{PGE}_{2}$-matured DCs cotransfected with mRNA encoding IL-12p70 and a tumor-associated antigen effectively secrete IL-12p70 and induce high avidity tumorspecific $\mathrm{T}$ cell responses in vitro [32].

Previously, we reported efficient ex vivo detection of HIV-1-specific immune responses in untreated HIV-1seropositive persons [16], although they have a rather damaged immune system [59]. With the ultimate aim to develop an immunotherapy based on DCs, we subsequently provided proof of principle for the use of gag mRNAelectroporated monocyte-derived mature DCs as a possible strategy to improve T cell immunity under HAART $[17,60]$. Consistent with our original hypothesis, the results presented here confirm the effective ability of gag-expressing DCs to expand functional HIV-specific $\mathrm{CD}^{+} \mathrm{T}$ cell responses. However, while it has been previously reported by others that IL-12p70-secreting DC preparations are always better for polarizing allogeneic $\mathrm{CD} 4^{+} \mathrm{T}$ cells and for sensitizing $\mathrm{CD} 8^{+}$ $\mathrm{T}$ cells to tumor antigens compared to DCs secreting little or no IL-12p70 [30-32], we were unable to find a superior effect of IL-12p70-producing gag mRNA-electroporated DCs to induce and expand HIV-1 gag-specific $\mathrm{CD}^{+} \mathrm{T}$ cells. In 




(a)

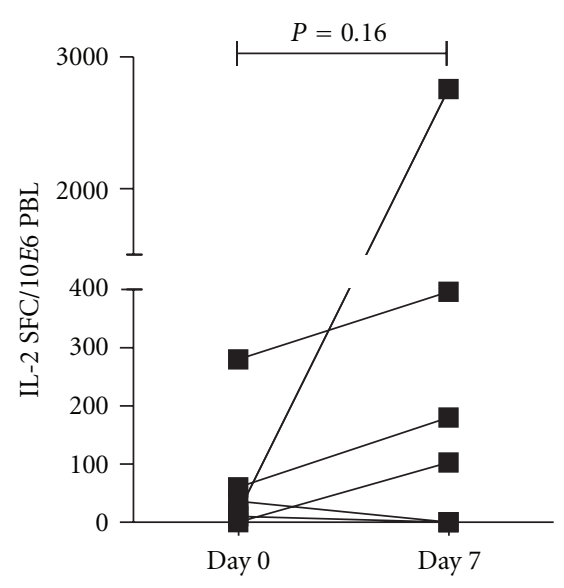

(b)



(c)

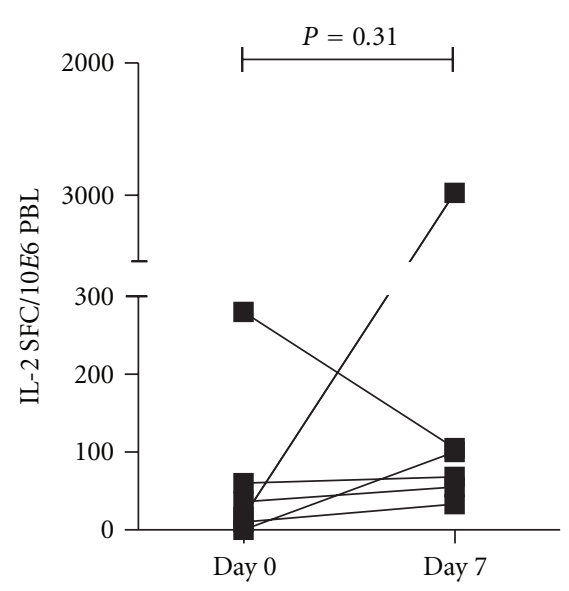

(d)

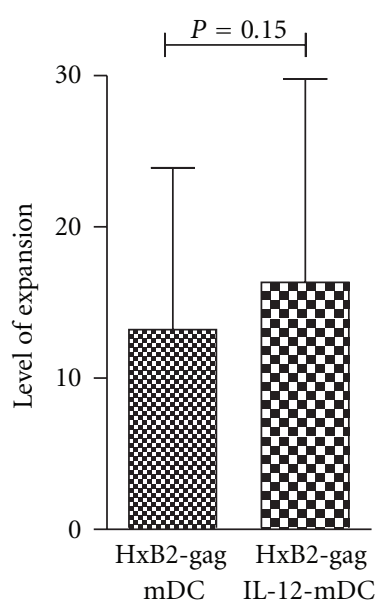

(e)

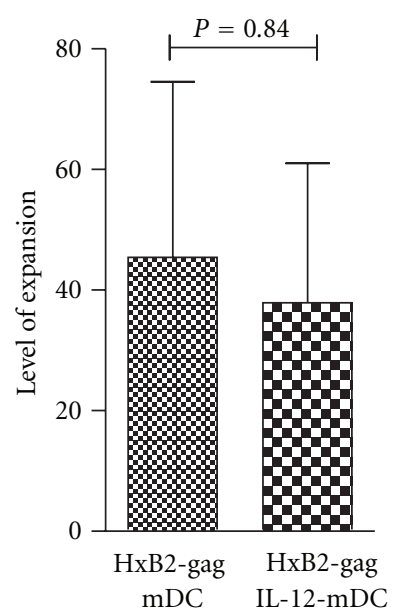

(f)

FIGURE 2: Effect of coelectroporation of DCs with $I L-12 p 70$ mRNA on HIV gag-specific T cell responses after 1 week of stimulation. Freshly thawed PBLs were directly incubated in ELISpot with HIV gag-derived peptides (Day 0) or PBLs were stimulated for one week with autologous HIV gag mRNA-electroporated DCs. For this, DCs were either matured with a simplified cytokine cocktail (TNF- $\alpha$ and $\mathrm{PGE}_{2}$ ) (a) and (b) or DCs were matured with this simplified cytokine cocktail in combination with $I L-12 p 70$ mRNA electroporation (c) and (d). Thereafter, cocultured PBLs were restimulated with HIV gag-derived peptides and evaluated in ELISpot for detection of antigen-specific IFN- $\gamma$ (a), (c) and (e) or IL-2 (b), (d), and (f) secretion. Results are shown as mean of triplicate analyses for each donor displaying a positive response $(n=6)$, as defined in the Materials and Methods section.

doing so, we confirm the finding by Soares et al. that IL- 12 is not mandatory for the Th1-inducing function of DCs [61]. Whether our observations are the results of an influence of HIV load on CTL responses cannot be ruled out and will need to be further investigated. However, we do not discount that other additional functions of antigen-specific $\mathrm{CD} 8^{+} \mathrm{T}$ cells that we have not analyzed, such as cytotoxicity and production of other soluble mediators, such as MIP- $1 \beta$ and TNF- $\alpha$, could be influenced by stimulation with immunemodulated hHxB-2 gag mRNA-electroporated DCs. Indeed, others have shown that the quality of the $\mathrm{CD} 8^{+} \mathrm{T}$ cell response, that is, polyfunctional $\mathrm{CD} 8^{+} \mathrm{T}$ cells, is critically involved in viral suppression $[62,63]$, as it seems to be the case in long-term nonprogressors (LTNPs) and elite controllers (ECs) [64]. In addition to priming of $\mathrm{T}$ cells, the group of Banchereau has recently demonstrated that DCs may also directly signal naïve $B$ cell differentiation through the production of IL-12p70 [65] and indirectly by promoting the differentiation of IL-21-producing $\mathrm{T}$ follicular helper (Tfh) cells $[66,67]$. Although we were not able to demonstrate its critical role in cell-mediated immunity in HIV-infected patients in our experiments, these observations suggest that IL- 12 p70 could constitute a potent vaccine adjuvant in situations that may require both arms of the immune system, such as HIV [68]. Indeed, studies with rhesus macaques have concluded that IL-12p70 enhances the induction of specific antibody responses in vivo when used as vaccine adjuvant [69-71]. On the other hand, Traxlmayr et al. revealed a potential negative effect of peripheral blood $\gamma \delta \mathrm{T}$ cells on $\mathrm{CD}^{+}$and $\mathrm{CD} 8^{+}$immune responses 


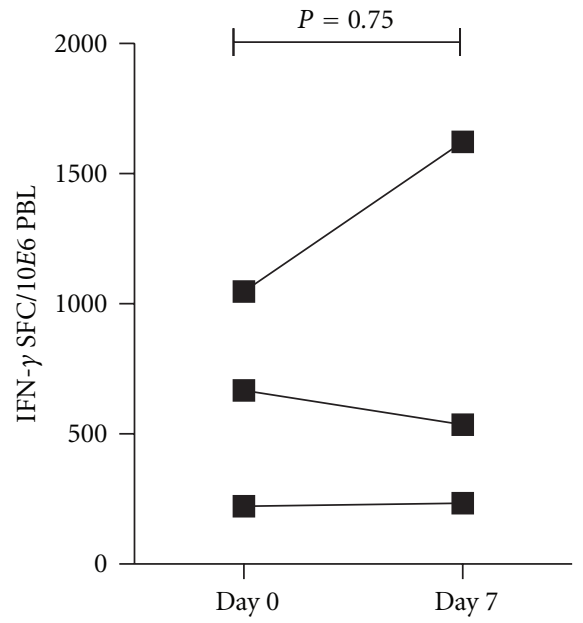

(a)

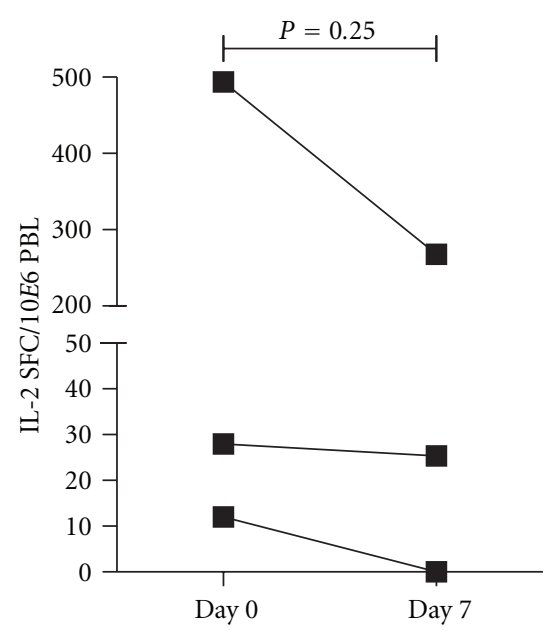

(b)

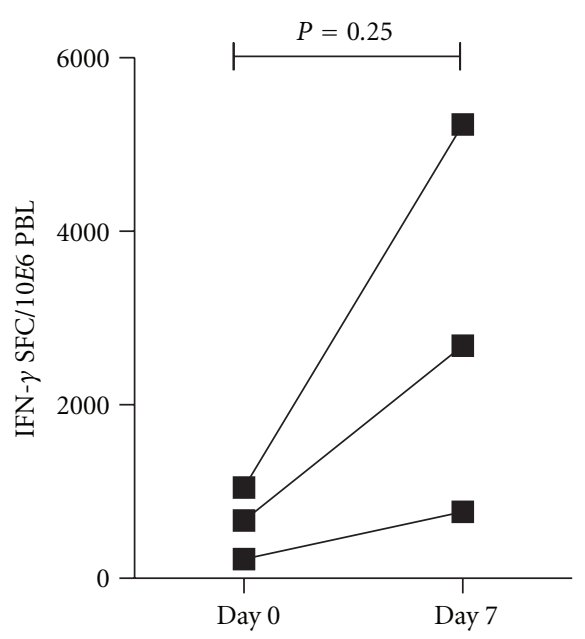

(c)

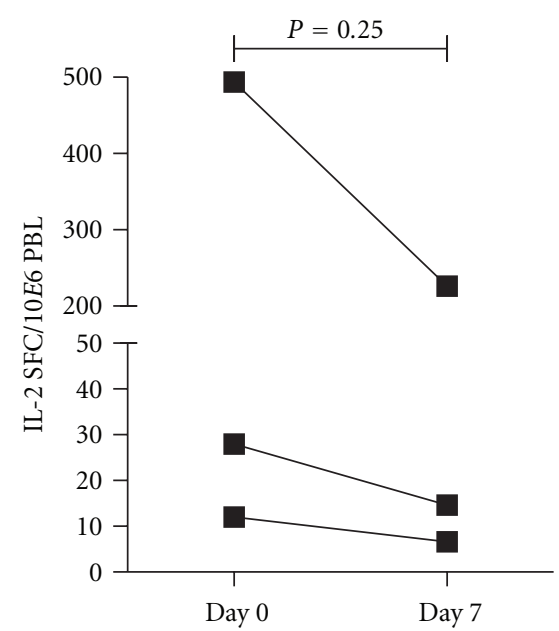

(d)

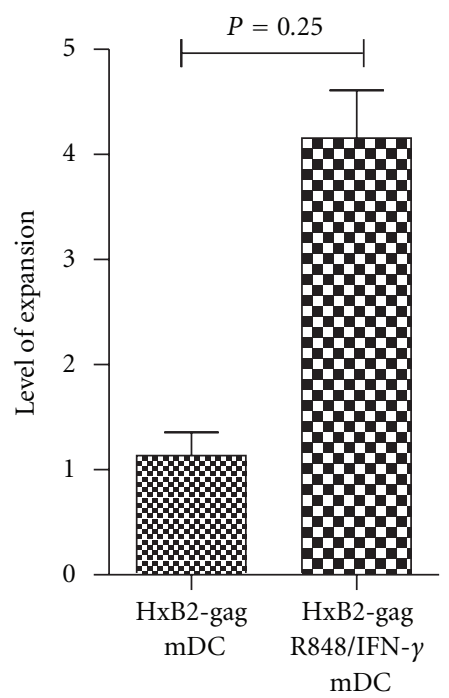

(e)

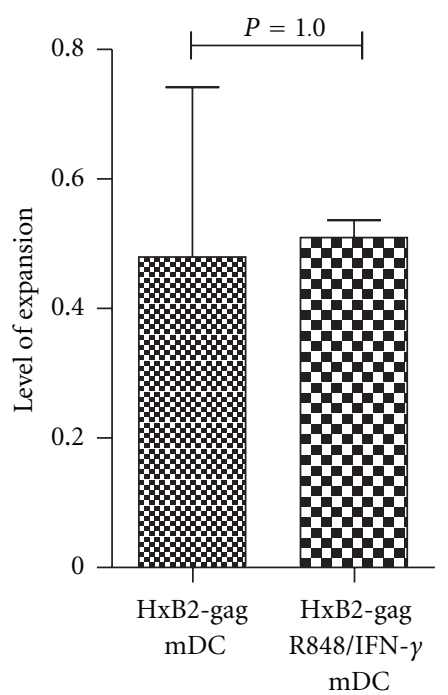

(f)

FIGURE 3: Effect of addition of TLR7/8 ligand, R848, and IFN- $\gamma$ for activation of DCs on HIV gag-specific T cell responses after 1 week of stimulation. Freshly thawed PBLs were directly incubated in ELISpot with HIV gag-derived peptides (Day 0) or PBLs were stimulated for one week with autologous HIV gag mRNA-electroporated DCs. For this, DCs were either matured with a simplified cytokine cocktail (TNF- $\alpha$ and $\mathrm{PGE}_{2}$ ) (a) and (b) or DCs were matured with a simplified cytokine cocktail in combination with TLR7/8 ligand resiquimod (R848) and IFN- $\gamma(\mathrm{c})$ and (d). Thereafter, cocultured PBLs were restimulated with HIV gag-derived peptides and evaluated in ELISpot for detection of antigen-specific IFN- $\gamma$ (a), (c), and (e) or IL-2 (b, d, and f) secretion. Results are shown as mean of triplicate analyses for each donor displaying a positive response $(n=3)$, as defined in the Materials and Methods section.

in cancer patients undergoing immune therapy with IL12p70-secreting DCs [72]. They suggest that IL-12-mediated triggering of $\gamma \delta \mathrm{T}$ cells may be part of a negative feedback mechanism for DC-controlled immune responses.

Previously, it has been shown by others that vaccines are only effective in models of persistent virus infection if they induce long-term immunological memory [73]. In support of this hypothesis, studies in macaques have shown that strong and early $\mathrm{T}$ cell responses can be generated by various vaccination regimens. However, none of these responses was long-lasting, as evidenced by a rapid decline of all generated beneficial immune responses [74-76]. We demonstrated here that stimulation of PBLs from HIV-infected patients with hHxB-2 gag mRNA-electroporated DCs maintained HIV1 gag-specific IFN- $\gamma$ - and IL-2-producing $\mathrm{T}$ cells in most instances.

In conclusion, while hHxB-2 gag mRNA-electroporated DCs expanded the number of HIV-1 gag-specific T cells, we were not able to further improve immune responses by immune modulation of DCs, that is, IL-12p70 mRNA 


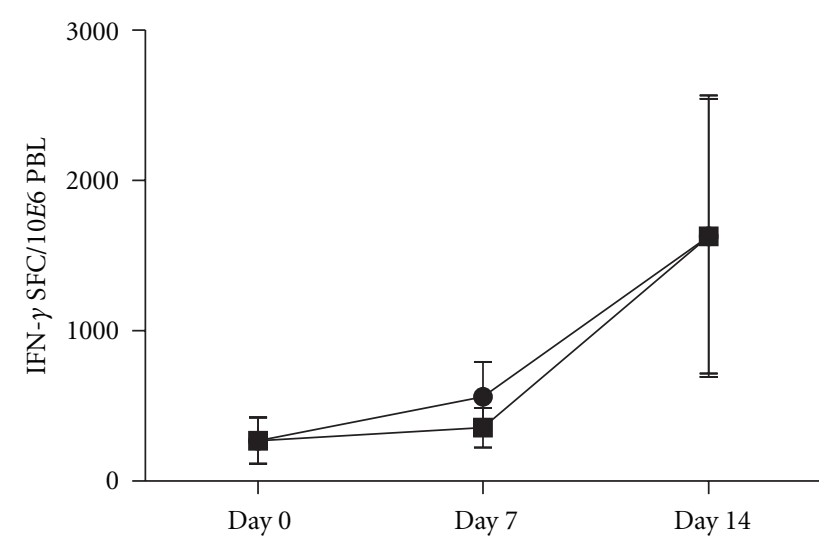

-- Cytokine cocktail-matured DC

IL-12-electroporated mature DC

(a)

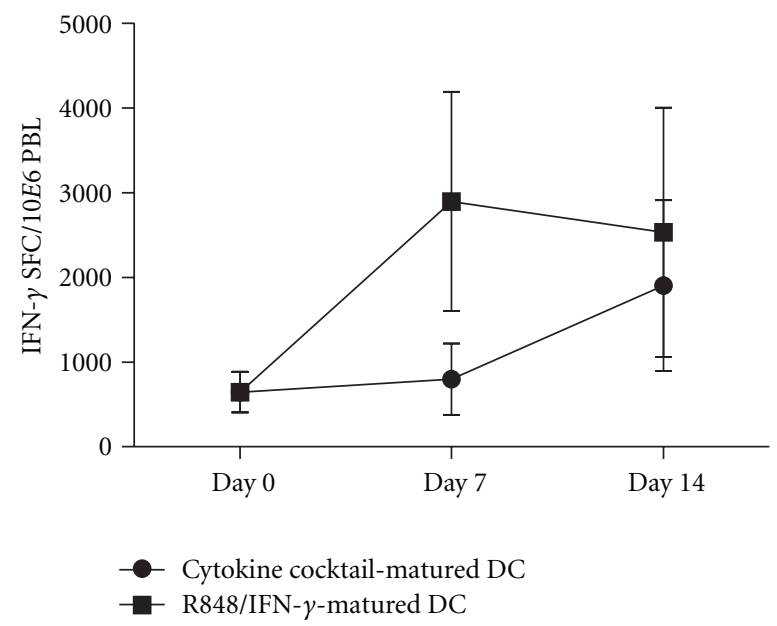

(c)

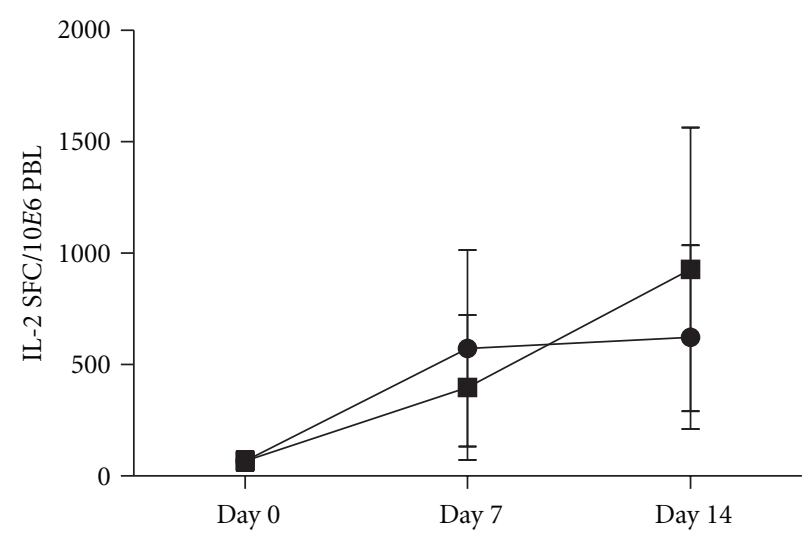

-- Cytokine cocktail-matured DC

- IL-12-electroporated mature DC

(b)

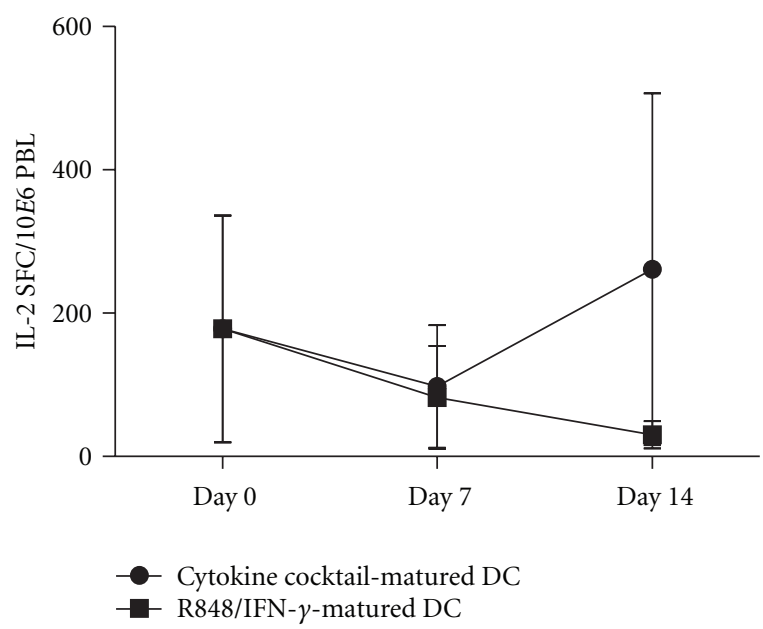

(d)

FIGURE 4: Stimulatory capacity of DCs from HIV-seropositive individuals after a second stimulation round. Freshly thawed PBLs were directly incubated in ELISpot with gag-derived peptides (Day 0), or PBLs were stimulated for one week with autologous gag mRNAelectroporated DCs (day 7), or PBLs were stimulated for a second week with thawed autologous electroporated DCs and reevaluated in ELISpot (day 14). For this, DCs were matured with a simplified cytokine cocktail (TNF- $\alpha$ and $\mathrm{PGE}_{2}$ ) or with a simplified cytokine cocktail in combination with $I L-12 p 70$ mRNA electroporation (a) and (b), or with a simplified cytokine cocktail in combination with TLR7/8 ligand resiquimod (R848), and IFN- $\gamma$ (c) and (d). Cocultured PBLs were evaluated for antigen-specific secretion of the following cytokines: IFN- $\gamma$ (a) and (c) and IL-2 (b) and (d). Results are shown as mean of triplicate analyses for each donor displaying a positive response $(n=2)$, as defined in the Materials and Methods section.

cotransfection of DCs or activation of DCs with potential danger signals such as R848 and IFN- $\gamma$. Since we do not rule out effects on other arms of the immune system that may contribute to the control of HIV replication, we will further evaluate and refine this approach to develop consistent and long-lasting enhancement of immune responses with the ultimate aim of using them in therapeutic settings.

\section{Authors' Contribution}

Ellen Van Gulck and Nathalie Cools contributed equally to the study and are cofirst authors. Conceived and designed the experiments: EVG, NC, VVT, ZB, GV. Performed the experiments: EVG, NC, DA, LB, KV. Analyzed the data: EVG, NC. Contributed reagents/materials/analysis tools: KV, MV, ZB, GV. Wrote the paper: EVG, NC, ZB, GV.

\section{Acknowledgments}

The authors thank the AIDS Reference Laboratory (ARL) of ITMA for the collection and coding and anonymous registration of samples. They also thank the NIH AIDS Research and Reference Reagent Program for providing the HIV-1 gag peptide pool. This work was supported by a grant from IUAP (Inter-University Attraction Poles, P6/41 of the 
Belgian government), by a grant of the Hercules FoundationBelgium, and by research grants of the Foundation Against Cancer (Stichting tegen Kanker). N. Cools is a postdoctoral fellow of the Fund for Scientific Research (FWO)-Flanders.

\section{References}

[1] R. A. Koup, J. T. Safrit, Y. Cao et al., "Temporal association of cellular immune responses with the initial control of viremia in primary human immunodeficiency virus type 1 syndrome," Journal of Virology, vol. 68, no. 7, pp. 4650-4655, 1994.

[2] P. Borrow, H. Lewicki, B. H. Hahn, G. M. Shaw, and M. B. A. Oldstone, "Virus-specific $\mathrm{CD}^{+}$cytotoxic T-lymphocyte activity associated with control of viremia in primary human immunodeficiency virus type 1 infection," Journal of Virology, vol. 68, no. 9, pp. 6103-6110, 1994.

[3] S. A. Migueles, A. C. Laborico, W. L. Shupert et al., "HIVspecific $\mathrm{CD}^{+} \mathrm{T}$ cell proliferation is coupled to perforin expression and is maintained in nonprogressors," Nature Immunology, vol. 3, no. 11, pp. 1061-1068, 2002.

[4] C. Hess, M. Altfeld, S. Y. Thomas et al., "HIV-1 specific $\mathrm{CD}^{+} \mathrm{T}$ cells with an effector phenotype and control of viral replication," The Lancet, vol. 363, no. 9412, pp. 863-866, 2004.

[5] G. Pantaleo and R. A. Koup, "Correlates of immune protection in HIV-1 infection: what we know, what we don't know, what we should know," Nature Medicine, vol. 10, no. 8, pp. 806-810, 2004.

[6] J. M. Benito, M. López, and V. Soriano, "The role of CD8 ${ }^{+}$Tcell response in HIV infection," AIDS Reviews, vol. 6, no. 2, pp. 79-88, 2004.

[7] M. R. Betts, D. R. Ambrozak, D. C. Douek et al., "Analysis of total human immunodeficiency virus (HIV)-specific CD4 ${ }^{+}$ and $\mathrm{CD}^{+}$T-cell responses: relationship to viral load in untreated HIV infection," Journal of Virology, vol. 75, no. 24, pp. 11983-11991, 2001.

[8] M. López, V. Soriano, N. Rallón, A. Cascajero, J. GonzálezLahoz, and J. M. Benito, "Suppression of viral replication with highly active antiretroviral therapy has no impact on the functional profile of HIV-specific CD8 ${ }^{+}$T cells," European Journal of Immunology, vol. 38, no. 6, pp. 1548-1558, 2008.

[9] S. A. Migueles, K. A. Weeks, E. Nou et al., "Defective human immunodeficiency virus-specific $\mathrm{CD} 8^{+} \mathrm{T}$-cell polyfunctionality, proliferation, and cytotoxicity are not restored by antiretroviral therapy," Journal of Virology, vol. 83, no. 22, pp. 11876-11889, 2009.

[10] D. C. Douek, P. D. Kwong, and G. J. Nabel, "The rational design of an AIDS vaccine," Cell, vol. 124, no. 4, pp. 677-681, 2006.

[11] B. Autran, R. L. Murphy, D. Costagliola et al., "Greater viral rebound and reduced time to resume antiretroviral therapy after therapeutic immunization with the ALVAC-HIV vaccine (vCP1452)," AIDS, vol. 22, no. 11, pp. 1313-1322, 2008.

[12] L. Papagno, G. Alter, L. Assoumou et al., "Comprehensive analysis of virus-specific T-cells provides clues for the failure of therapeutic immunization with ALVAC-HIV vaccine," AIDS, vol. 25, no. 1, pp. 27-36, 2011.

[13] N. Cools, P. Ponsaerts, V. F. I. Van Tendeloo, and Z. N. Berneman, "Balancing between immunity and tolerance: an interplay between dendritic cells, regulatory $\mathrm{T}$ cells, and effector T cells," Journal of Leukocyte Biology, vol. 82, no. 6, pp. 1365-1374, 2007.
[14] N. Cools, A. Petrizzo, E. Smits et al., "Dendritic cells in the pathogenesis and treatment of human diseases: a Janus Bifrons?" Immunotherapy, vol. 3, no. 10, pp. 1203-1222, 2011.

[15] E. Gilboa, "DC-based cancer vaccines," The Journal of Clinical Investigation, vol. 117, no. 5, pp. 1195-1203, 2007.

[16] E. R. A. Van Gulck, P. Ponsaerts, L. Heyndrickx et al., "Efficient stimulation of HIV-1-specific T cells using dendritic cells electroporated with mRNA encoding autologous HIV-1 gag and Env proteins," Blood, vol. 107, no. 5, pp. 1818-1827, 2006.

[17] E. R. Van Gulck, G. Vanham, L. Heyndrickx et al., "Efficient in vitro expansion of human immunodeficiency virus (HIV)specific T-cell responses by gag mRNA-electroporated dendritic cells from treated and untreated HIV type 1-infected individuals," Journal of Virology, vol. 82, no. 7, pp. 3561-3573, 2008.

[18] V. F. I. Van Tendeloo, P. Ponsaerts, F. Lardon et al., "Highly efficient gene delivery by mRNA electroporation in human hematopoietic cells: superiority to lipofection and passive pulsing of mRNA and to electroporation of plasmid cDNA for tumor antigen loading of dendritic cells," Blood, vol. 98, no. 1, pp. 49-56, 2001.

[19] D. Boczkowski, S. K. Nair, D. Snyder, and E. Gilboa, "Dendritic cells pulsed with RNA are potent antigen-presenting cells in vitro and in vivo," Journal of Experimental Medicine, vol. 184, no. 2, pp. 465-472, 1996.

[20] D. Chassin, M. Andrieu, W. Cohen et al., "Dendritic cells transfected with the nef genes of HIV-1 primary isolates specifically activate cytotoxic T lymphocytes from seropositive subjects," European Journal of Immunology, vol. 29, no. 1, pp. 196-202, 1999.

[21] C. Geldmacher, C. Gray, M. Nason et al., "A high viral burden predicts the loss of CD8 T-cell responses specific for subdominant gag epitopes during chronic human immunodeficiency virus infection," Journal of Virology, vol. 81, no. 24, pp. 1380913815, 2007.

[22] D. G. Kavanagh, D. E. Kaufmann, S. Sunderji et al., "Expansion of HIV-specific $\mathrm{CD}^{+}$and $\mathrm{CD}^{+}{ }^{+} \mathrm{T}$ cells by dendritic cells transfected with mRNA encoding cytoplasm- or lysosometargeted Nef," Blood, vol. 107, no. 5, pp. 1963-1969, 2006.

[23] N. M. Melhem, X. D. Liu, D. Boczkowski, E. Gilboa, and S. M. Barratt-Boyes, "Robust $\mathrm{CD}^{+}$and $\mathrm{CD}^{+} \mathrm{T}$ cell responses to SIV using mRNA-transfected DC expressing autologous viral Ag," European Journal of Immunology, vol. 37, no. 8, pp. 21642173, 2007.

[24] S. Sæbøe-Larssen, E. Fossberg, and G. Gaudernack, "mRNAbased electrotransfection of human dendritic cells and induction of cytotoxic T lymphocyte responses against the telomerase catalytic subunit (hTERT)," Journal of Immunological Methods, vol. 259, no. 1-2, pp. 191-203, 2002.

[25] I. Strobel, S. Berchtold, A. Götze, U. Schulze, G. Schuler, and A. Steinkasserer, "Human dendritic cells transfected with either RNA or DNA encoding influenza matrix protein M1 differ in their ability to stimulate cytotoxic T lymphocytes," Gene Therapy, vol. 7, no. 23, pp. 2028-2035, 2000.

[26] H. Jonuleit, U. Kühn, G. Müller et al., "Pro-inflammatory cytokines and prostaglandins induce maturation of potent immunostimulatory dendritic cells under fetal calf serum-free conditions," European Journal of Immunology, vol. 27, no. 12, pp. 3135-3142, 1997.

[27] A. Van Driessche, A. L. R. Van De Velde, G. Nijs et al., "Clinical-grade manufacturing of autologous mature mRNAelectroporated dendritic cells and safety testing in acute myeloid leukemia patients in a phase i dose-escalation clinical trial," Cytotherapy, vol. 11, no. 5, pp. 653-668, 2009. 
[28] S. N. Markovic, A. B. Dietz, C. W. Greiner et al., "Preparing clinical-grade myeloid dendritic cells by electroporationmediated transfection of in vitro amplified tumor-derived mRNA and safety testing in stage IV malignant melanoma," Journal of Translational Medicine, vol. 4, article 35, 2006.

[29] T. Luft, M. Jefford, P. Luetjens et al., "Functionally distinct dendritic cell (DC) populations induced by physiologic stimuli: prostaglandin $\mathrm{E}_{2}$ regulates the migratory capacity of specific DC subsets," Blood, vol. 100, no. 4, pp. 1362-1372, 2002.

[30] T. Felzmann, K. G. Hüttner, S. K. Breuer et al., "Semi-mature IL-12 secreting dendritic cells present exogenous antigen to trigger cytolytic immune responses," Cancer Immunology, Immunotherapy, vol. 54, no. 8, pp. 769-780, 2005.

[31] K. G. Hüttner, S. K. Breuer, P. Paul, O. Majdic, A. Heitger, and T. Felzmann, "Generation of potent anti-tumor immunity in mice by interleukin-12- secreting dendritic cells," Cancer Immunology, Immunotherapy, vol. 54, no. 1, pp. 67-77, 2005.

[32] H. J. Bontkes, D. Kramer, J. J. Ruizendaal et al., "Dendritic cells transfected with interleukin-12 and tumor-associated antigen messenger RNA induce high avidity cytotoxic T cells," Gene Therapy, vol. 14, no. 4, pp. 366-375, 2007.

[33] A. Langenkamp, M. Messi, A. Lanzavecchia, and F. Sallusto, "Kinetics of dendritic cell activation: impact on priming of TH1,TH2 and nonpolarized T cells," Nature Immunology, vol. 1, no. 4, pp. 311-316, 2000.

[34] C. Reis e Sousa, G. Yap, O. Schulz et al., "Paralysis of dendritic cell IL-12 production by microbial products prevents infection-induced immunopathology," Immunity, vol. 11, no. 5, pp. 637-647, 1999.

[35] P. Kaliński, J. H. N. Schuitemaker, C. M. U. Hilkens, E. A. Wierenga, and M. L. Kapsenberg, "Final maturation of dendritic cells is associated with impaired responsiveness to IFN- $\gamma$ and to bacterial IL-12 inducers: decreased ability of mature dendritic cells to produce IL-12 during the interaction with Th cells," Journal of Immunology, vol. 162, no. 6, pp. 3231-3236, 1999.

[36] P. L. Vieira, E. C. De Jong, E. A. Wierenga, M. L. Kapsenberg, and P. Kaliński, "Development of Th1-inducing capacity in myeloid dendritic cells requires environmental instruction," Journal of Immunology, vol. 164, no. 9, pp. 4507-4512, 2000.

[37] A. C. I. Boullart, E. H. J. G. Aarntzen, P. Verdijk et al., "Maturation of monocyte-derived dendritic cells with Toll-like receptor 3 and 7/8 ligands combined with prostaglandin $E_{2}$ results in high interleukin-12 production and cell migration," Cancer Immunology, Immunotherapy, vol. 57, no. 11, pp. 15891597, 2008.

[38] A. Bojak, J. Wild, L. Deml, and R. Wagner, "Impact of codon usage modification on T cell immunogenicity and longevity of HIV-1 gag-specific DNA vaccines," Intervirology, vol. 45, no. 4-6, pp. 275-286, 2002.

[39] N. Romani, S. Gruner, D. Brang et al., "Proliferating dendritic cell progenitors in human blood," Journal of Experimental Medicine, vol. 180, no. 1, pp. 83-93, 1994.

[40] P. Ponsaerts, V. F. I. Van Tendeloo, N. Cools et al., "mRNAelectroporated mature dendritic cells retain transgene expression, phenotypical properties and stimulatory capacity after cryopreservation," Leukemia, vol. 16, no. 7, pp. 1324-1330, 2002.

[41] S. Janetzki, K. S. Panageas, L. Ben-Porat et al., "Results and harmonization guidelines from two large-scale international Elispot proficiency panels conducted by the Cancer Vaccine Consortium (CVC/SVI)," Cancer Immunology, Immunother$a p y$, vol. 57, no. 3, pp. 303-315, 2008.
[42] Z. Moodie, L. Price, S. Janetzki, and C. M. Britten, "Response determination criteria for ELISPOT: toward a standard that can be applied across laboratories," Methods in Molecular Biology, vol. 792, pp. 185-196, 2012.

[43] W. Lu, L. C. Arraes, W. T. Ferreira, and J. M. Andrieu, "Therapeutic dendritic-cell vaccine for chronic HIV-1 infection," Nature Medicine, vol. 10, no. 12, pp. 1359-1365, 2004.

[44] W. Lu, X. Wu, Y. Lu, W. Guo, and J. M. Andrieu, "Therapeutic dendritic-cell vaccine for simian aids," Nature Medicine, vol. 9, no. 1, pp. 27-32, 2003.

[45] S. K. Kundu, M. Dupuis, A. Sette et al., "Role of preimmunization virus sequences in cellular immunity in HIVinfected patients during HIV type $1 \mathrm{MN}$ recombinant gp160 immunization," AIDS Research and Human Retroviruses, vol. 14, no. 18, pp. 1669-1678, 1998.

[46] F. García, M. Lejeune, N. Climent et al., "Therapeutic immunization with dendritic cells loaded with heat-inactivated autologous HIV-1 in patients with chronic HIV-1 infection," Journal of Infectious Diseases, vol. 191, no. 10, pp. 1680-1685, 2005.

[47] F. García, N. Climent, L. Assoumou et al., "A therapeutic dendritic cell-based vaccine for HIV-1 infection," Journal of Infectious Diseases, vol. 203, no. 4, pp. 473-478, 2011.

[48] F. Ide, T. Nakamura, M. Tomizawa et al., "Peptide-loaded dendritic-cell vaccination followed by treatment interruption for chronic HIV-1 infection: a phase 1 trial," Journal of Medical Virology, vol. 78, no. 6, pp. 711-718, 2006.

[49] N. C. Connolly, T. L. Whiteside, C. Wilson, V. Kondragunta, C. R. Rinaldo, and S. A. Riddler, "Therapeutic immunization with human immunodeficiency virus type 1 (HIV-1) peptideloaded dendritic cells is safe and induces immunogenicity in HIV-1-infected individuals," Clinical and Vaccine Immunology, vol. 15, no. 2, pp. 284-292, 2008.

[50] R. T. Gandhi, D. O’Neill, R. J. Bosch et al., “A randomized therapeutic vaccine trial of canarypox-HIV-pulsed dendritic cells vs. canarypox-HIV alone in HIV-1-infected patients on antiretroviral therapy," Vaccine, vol. 27, no. 43, pp. 6088-6094, 2009.

[51] H. Kloverpris, I. Karlsson, J. Bonde et al., "Induction of novel $\mathrm{CD}^{+}{ }^{+} \mathrm{T}$-cell responses during chronic untreated HIV1 infection by immunization with subdominant cytotoxic Tlymphocyte epitopes," AIDS, vol. 23, no. 11, pp. 1329-1340, 2009.

[52] J. P. Routy, M. R. Boulassel, B. Yassine-Diab et al., "Immunologic activity and safety of autologous HIV RNAelectroporated dendritic cells in HIV-1 infected patients receiving antiretroviral therapy," Clinical Immunology, vol. 134, no. 2, pp. 140-147, 2010.

[53] P. Kaliński, C. M. U. Hilkens, E. A. Wierenga, and M. L. Kapsenberg, "T-cell priming by type- 1 and type- 2 polarized dendritic cells: the concept of a third signal," Immunology Today, vol. 20, no. 12, pp. 561-567, 1999.

[54] G. Van Kooten and J. Banchereau, "CD40-CD40 ligand," Journal of Leukocyte Biology, vol. 67, no. 1, pp. 2-17, 2000.

[55] M. Croft, "Co-stimulatory members of the TNFR family: keys to effective T-cell immunity?" Nature Reviews Immunology, vol. 3, no. 8, pp. 609-620, 2003.

[56] D. J. Lenschow, T. L. Walunas, and J. A. Bluestone, "CD28/B7 system of T cell costimulation," Annual Review of Immunology, vol. 14, pp. 233-258, 1996.

[57] G. Trinchieri, S. Pflanz, and R. A. Kastelein, "The IL-12 family of heterodimeric cytokines: new players in the regulation of $\mathrm{T}$ cell responses," Immunity, vol. 19, no. 5, pp. 641-644, 2003. 
[58] A. Zobywalski, M. Javorovic, B. Frankenberger et al., "Generation of clinical grade dendritic cells with capacity to produce biologically active IL-12p70," Journal of Translational Medicine, vol. 5, article 18, 2007.

[59] B. E. Palmer, E. Boritz, N. Blyveis, and C. C. Wilson, "Discordance between frequency of human immunodeficiency virus type 1 (HIV-1)-specific gamma interferon-producing $\mathrm{CD}^{+} \mathrm{T}$ cells and HIV-1-specific lymphoproliferation in HIV1 -infected subjects with active viral replication," Journal of Virology, vol. 76, no. 12, pp. 5925-5936, 2002.

[60] E. Van Gulck, E. Vlieghe, M. Vekemans et al., "MRNAbased dendritic cell vaccination induces potent antiviral T-cell responses in HIV-1-infected patients," AIDS, vol. 26, no. 4, pp. F1-F12, 2012.

[61] H. Soares, H. Waechter, N. Glaichenhaus et al., "A subset of dendritic cells induces CD4 ${ }^{+} \mathrm{T}$ cells to produce IFN- $\gamma$ by an IL-12-independent but CD70-dependent mechanism in vivo," Journal of Experimental Medicine, vol. 204, no. 5, pp. 10951106, 2007.

[62] S. C. Zimmerli, A. Harari, C. Cellerai, F. Vallelian, P. A. Bart, and G. Pantaleo, "HIV-1-specific IFN- $\gamma /$ IL-2-secreting CD8 T cells support CD4-independent proliferation of HIV1-specific CD8 T cells," Proceedings of the National Academy of Sciences of the United States of America, vol. 102, no. 20, pp. 7239-7244, 2005.

[63] M. Lichterfeld, X. G. Yu, M. T. Waring et al., "HIV-1-specific cytotoxicity is preferentially mediated by a subset of $\mathrm{CD}^{+} \mathrm{T}$ cells producing both interferon- $\gamma$ and tumor necrosis factorж," Blood, vol. 104, no. 2, pp. 487-494, 2004.

[64] M. R. Betts, C. M. Gray, J. H. Cox, and G. Ferrari, "Antigenspecific T-cell-mediated immunity after HIV-1 infection: implications for vaccine control of HIV development," Expert Review of Vaccines, vol. 5, no. 4, pp. 505-516, 2006.

[65] B. Dubois, C. Massacrier, B. Vanbervliet et al., "Critical role of IL-12 in dendritic cell-induced differentiation of naive B lymphocytes," Journal of Immunology, vol. 161, no. 5, pp. 2223-2231, 1998.

[66] N. Schmitt, R. Morita, L. Bourdery et al., "Human dendritic cells induce the differentiation of interleukin-21-producing $\mathrm{T}$ follicular helper-like cells through interleukin-12," Immunity, vol. 31, no. 1, pp. 158-169, 2009.

[67] J. Banchereau, E. Klechevsky, N. Schmitt, R. Morita, K. Palucka, and H. Ueno, "Harnessing human dendritic cell subsets to design novel vaccines," Annals of the New York Academy of Sciences, vol. 1174, pp. 24-32, 2009.

[68] J. Chehimi, C. Paganin, I. Frank, S. Chouaib, S. Starr, and G. Trinchieri, "Interleukin-12 in the pathogenesis and therapy of HIV disease," Research in Immunology, vol. 146, no. 7-8, pp. 605-614, 1995.

[69] L. A. Hirao, L. Wu, A. S. Khan et al., "Combined effects of IL-12 and electroporation enhances the potency of DNA vaccination in macaques," Vaccine, vol. 26 , no. 25 , pp. 3112 3120, 2008.

[70] E. B. Schadeck, M. Sidhu, M. A. Egan et al., "A dose sparing effect by plasmid encoded IL-12 adjuvant on a SIVgag-plasmid DNA vaccine in rhesus macaques," Vaccine, vol. 24, no. 21, pp. 4677-4687, 2006.

[71] P. H. Van Der Meide, F. Villinger, A. A. Ansari et al., "Stimulation of both humoral and cellular immune responses to HIV-1 gp120 by interleukin-12 in Rhesus macaques," Vaccine, vol. 20, no. 17-18, pp. 2296-2302, 2002.

[72] M. W. Traxlmayr, D. Wesch, A. M. Dohnal et al., "Immune suppression by $\gamma \delta$ t-cells as a potential regulatory mechanism after cancer vaccination with IL-12 secreting dendritic cells," Journal of Immunotherapy, vol. 33, no. 1, pp. 40-52, 2010.

[73] J. Banatvala, P. Van Damme, and S. Oehen, "Lifelong protection against hepatitis $B$ : the role of vaccine immunogenicity in immune memory," Vaccine, vol. 19, no. 7-8, pp. 877-885, 2000.

[74] T. M. Allen, T. U. Vogel, D. H. Fuller et al., "Induction of AIDS virus-specific CTL activity in fresh, unstimulated peripheral blood lymphocytes from rhesus macaques vaccinated with a DNA prime/modified vaccinia virus Ankara boost regimen," Journal of Immunology, vol. 164, no. 9, pp. 4968-4978, 2000.

[75] R. R. Amara, F. Villinger, J. D. Altman et al., "Control of a mucosal challenge and prevention of AIDS by a multiprotein DNA/MVA vaccine," Science, vol. 292, no. 5514, pp. 69-74, 2001.

[76] T. Hanke and A. McMichael, "Pre-clinical development of a multi-CTL epitope-based DNA prime MVA boost vaccine for AIDS," Immunology Letters, vol. 66, no. 1-3, pp. 177-181, 1999. 


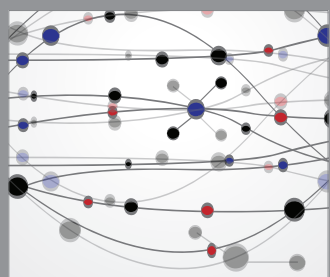

The Scientific World Journal
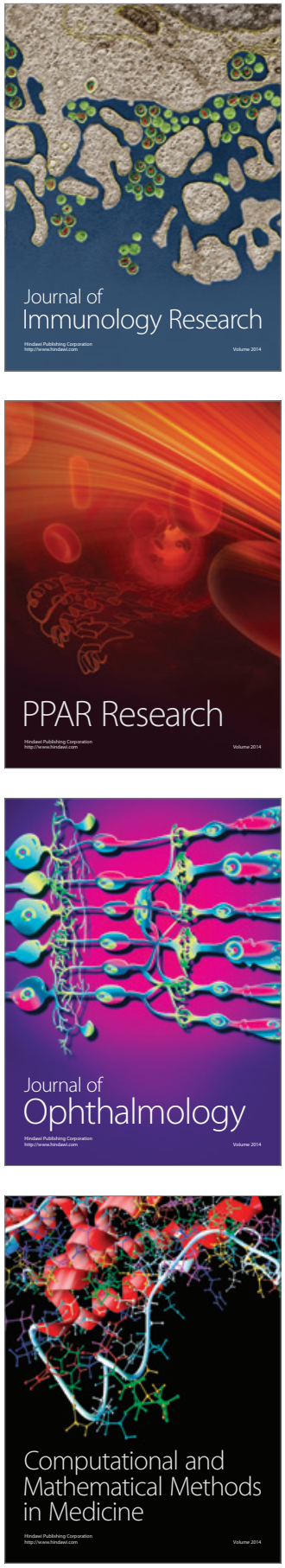

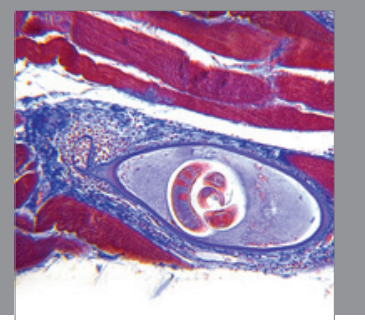

Gastroenterology

Research and Practice
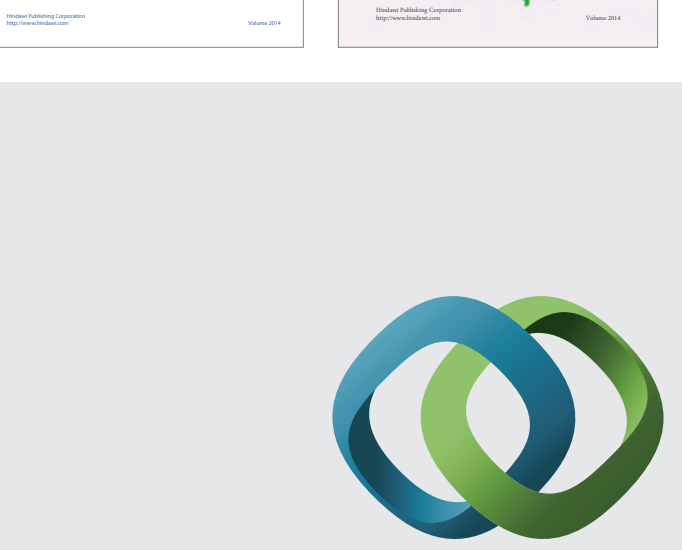

\section{Hindawi}

Submit your manuscripts at

http://www.hindawi.com
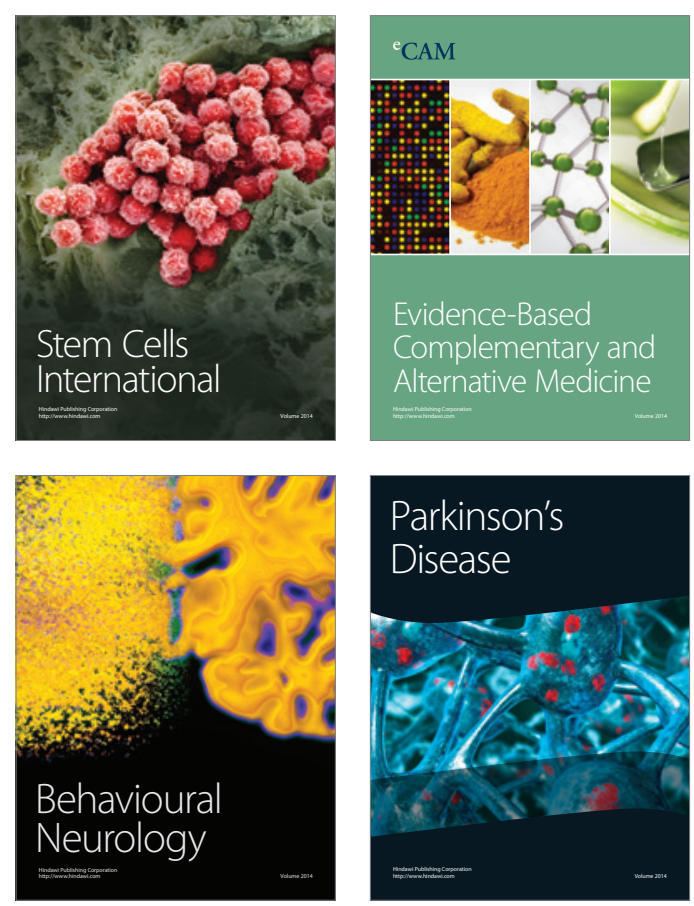

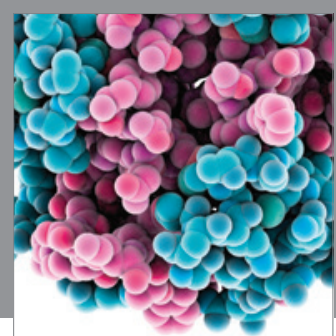

Journal of
Diabetes Research

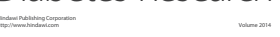

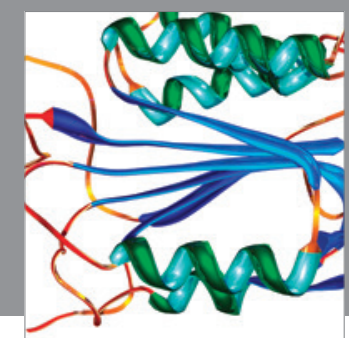

Disease Markers
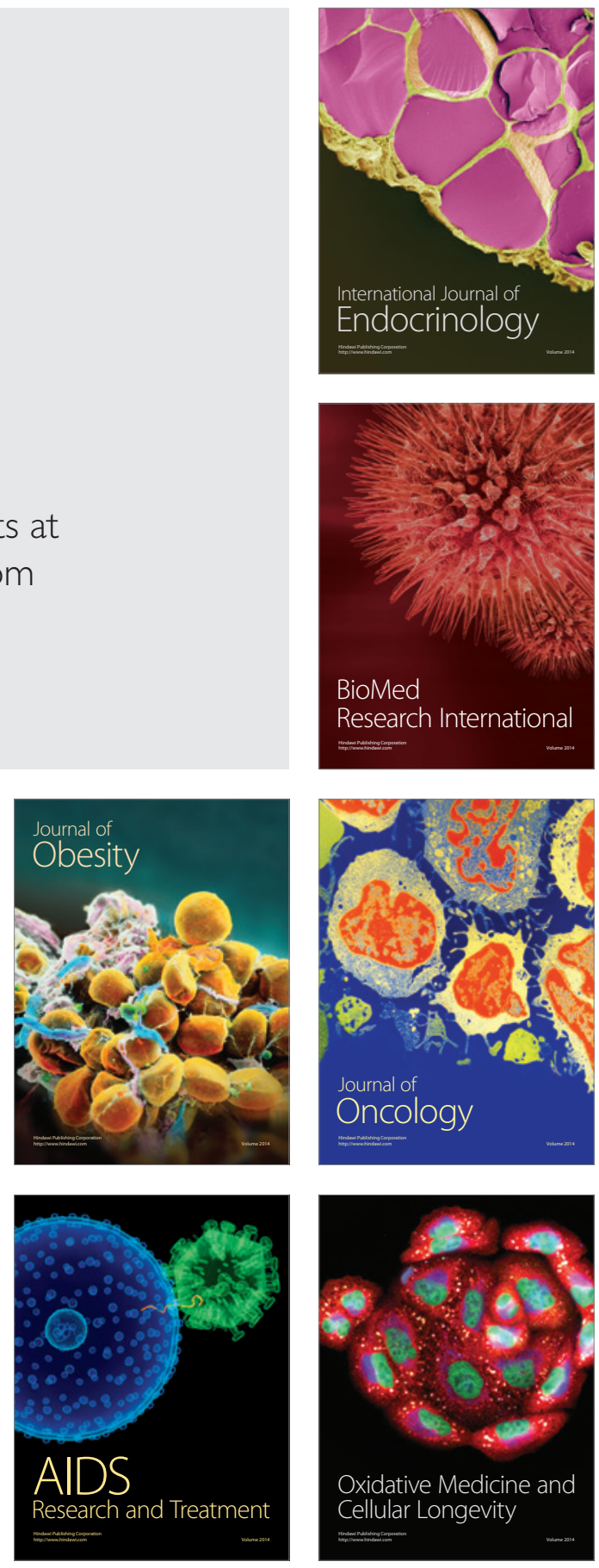